J. clin. Path. (1952), 5, 91.

\title{
THE EFFECTS OF A PHENOTHIAZINE DERIVATIVE (RP.3300) ON RED CELL PRESERVATION
}

\author{
BY \\ H. CHAPLIN, JUn., ${ }^{*}$ HAL CRAWFORD, MARIE CUTBUSH, AND \\ P. L. MOLLISON \\ From the Medical Research Council Blood Transfusion Research Unit, Postgraduate \\ Medical School of London
}

(RECEIVED FOR PUBLICATION JUNE 30, 1951)

In the course of a search for anti-histamine compounds Halpern (1947) found that a new group of drugs, derived from phenothiazine (thio-diphenyl-amine), was very active. In the following year Halpern and Hamburger (1948) gave a more detailed account of the effects of one of these derivatives, to which they gave the name " phenergan." It was subsequently reported that the phenothiazine derivatives possessed extraordinary power as histamine antagonists far exceeding that of previously described anti-histamine compounds which lacked the diphenyl radical but possessed the basic formula $\mathrm{R}-\mathrm{N}-\left(\mathrm{CH}_{2}\right)_{2}-\mathrm{N}\left\langle\mathrm{CH}_{3} \mathrm{CH}_{3}\right.$ (Halpern, 1950).

Halpern and Reuse (1949), working with these compounds on isolated animal tissues, made the interesting observation that frog muscle suspended in distilled water to which phenergan had been added failed to show the rapid tissue lysis observed in distilled water alone. In an isotonic solution containing phenergan tissues retained their normal histological appearance for periods of from 30 to 120 days. These studies were extended to other tissues (skin, liver, testicle, etc.) and similar effects were observed.

Halpern, Dreyfus, and Bourdon (1950) later studied the effects of these compounds on blood during storage. Blood was drawn into Wurmser's (1946) solution (citric acid, 3 g., sodium hydroxide, 1 g., water, 100 g., added to $400 \mathrm{ml}$. blood) and stored at $5^{\circ} \mathrm{C}$. for varying periods. Phenergan or the related compound RP.3300 was added to the Wurmser's solution to achieve final concentrations in the stored blood mixture of 1 in 10,000 and 1 in 25,000. In the blood samples preserved in the presence of phenothiazine derivatives it was found that $(a)$ the time of appearance of spontaneous haemolysis on storage was much delayed compared with the control samples ; $(b)$ the normal sedimentation of the cells following mixing was maintained far longer than in the control samples; (c) the normal tendency to rouleaux formation was maintained longer than in control samples ; $(d)$ the shape and volume of red cells (both in suspension and as judged in stained smears) remained normal for a longer time than in control samples; and $(e)$ the rise in the serum potassium level during

* U.S. Public Health Service Research Fellow of the National Institute of Health. 
storage was both delayed and decreased compared with control samples. Furthermore, Halpern and Bessis (1950) using electron and phase microscopy showed that red cells rendered spherical by repeated washing in physiological saline could be restored to their former biconcave shape by weak dilutions of phenothiazine derivatives.

It was pointed out that there was no correlation between the anti-histaminic potency of a given phenothiazine derivative and its ability to evoke these favourable changes in vitro in stored blood. For example, RP.3300 has almost no antihistaminic activity, yet has the most marked effect upon stored blood, whereas "neo-antergan" is strongly anti-histaminic, but has almost no effect on stored blood. Halpern suggested that the activity of these agents as tissue preservatives was most likely to be due to their power to inhibit enzymes, particularly cathepsins and tryptic enzymes.

Observations on white blood cells and platelets were less conclusive but, at least in so far as white cell staining and the resistance of white cells to spontaneous lysis during storage were concerned, the phenothiazine compounds seemed to exert a favourable effect. Preliminary transfusion experiments suggested that red cells stored with RP.3300 survived better in vivo than control red cells; however, only two or three experiments were performed.

In view of this encouraging report it was decided to try to confirm the findings of Halpern and his colleagues and, particularly, to carry out a more detailed study of the survival in human subjects of red cells stored with RP.3300.

\section{The Compound and Animal Toxicity Tests}

The Compound.-RP.3300 is a white crystalline powder; its hydrochloride has a molecular weight of 348.5 and has the following chemical structure :<smiles>CC(C)CN(C)CC1CCCCN1CC(C)C</smiles>

The compound is moderately soluble in distilled water, but a precipitate forms if the $p \mathrm{H}$ is raised above 7 , for example, by adding trisodium citrate.

A concentration of 1 in 1,000 of RP.3300 in distilled water lowers the surface tension of the water by 17 dynes (from 71); a concentration of 1 in 10,000 lowers the surface tension of water by 13 dynes.*

The compound in solution is relatively stable but, due to spontaneous oxidation, loses some of its activity after prolonged storage.

Toxicity Tests.- Since no information was available about the toxicity of the compound in man and there was only limited information about its toxicity in animals, the compound was submitted to Dr. Paton, of the National Institute for Medical Research. He found that in the chloralosed cat, RP.3300 in an intravenous dose of $1 \mathrm{mg} . / \mathrm{kg}$. caused a fall in blood pressure of $15 \mathrm{~mm}$. $\mathrm{Hg}$ lasting only one to two minutes; a dose of $4 \mathrm{mg}$. $/ \mathrm{kg}$. produced a fall of $60 \mathrm{~mm}$. $\mathrm{Hg}$. The fall in pressure was shown to be due, in

* The authors are indebted to Dr. W. D. M. Paton, of the National Institute for Medical Research, Mill Hill, London, for the measurement of the surface activity of RP.3300 and for the toxicity experiments on animals mentioned below. 
part at least, to a direct effect on the heart rather than to peripheral vasodilatation, since during the greater part of the depressor response limb volume decreased. This action of the drug was found to have a short latency, to resist atropine and " neo-antergan," and to be unaffected by vagotomy.

Dr. Paton suggested that the direct effect on the heart might well be due to the surface activity of the compound.

Respiration was unaffected by an intravenous dose of $1 \mathrm{mg} . / \mathrm{kg}$., but was profoundly, though transiently, depressed by $4 \mathrm{mg}$. $/ \mathrm{kg}$.; this effect was abolished by cutting the vagi.

In the mouse the LD50 of the drug was found to be between 20 and $50 \mathrm{mg}$. $/ \mathrm{kg}$.

\section{Transfusion Experiments}

In view of the results of the tests in animals, it was considered safe to transfuse blood containing a total dose of approximately $1-2 \mathrm{mg}$. RP.3300 per $\mathrm{kg}$. of the patient's body weight, administered slowly (in approximately one hour). The patient's pulse, respiration rate, and blood pressure were recorded at intervals during the transfusion and for 15 minutes afterwards.

The method of preparing the preservative solution was as follows: $50 \mathrm{mg}$. of RP.3300 dissolved in $5 \mathrm{ml}$. of distilled water were added to $120 \mathrm{ml}$. of the standard acid-citratedextrose solution and autoclaved immediately. A few days later $420 \mathrm{ml}$. of blood were drawn into the bottle and then stored at approximately $+2^{\circ} \mathrm{C}$. for periods ranging from 20 to 35 days. Blood was also drawn into the standard anticoagulant acid-citratedextrose solution, to which no RP.3300 had been added. These control bottles were taken at the same time as the test bottles and stored with them in the same refrigerator until the time of transfusion.

Two types of experiment were performed. In the first type, "single population," three recipients (group $O$, type $M$ ) each received approximately $500 \mathrm{ml}$. of a concentrated red cell suspension prepared from two bottles of group $\mathbf{O}$, type $\mathbf{N}$, blood of identical age, stored with RP.3300. In these cases the transfusion was completed in 30 to 70 minutes and a sample was taken from the patient five minutes after transfusion. The concentration of transfused red cells in this sample was taken as $100 \%$ survival; the counts of surviving red cells in subsequent samples were expressed as percentages of this initial figure. The resulting estimates of survival could be compared with earlier estimates made by the same method for red cells stored with acid-citrate-dextrose alone (Loutit and Mollison, 1943).

In the second type of experiment, which may conveniently be referred to as "double population" experiments, the patient received a transfusion of red cells stored without RP.3300, as well as a transfusion of red cells stored with RP.3300. Six experiments of this type were performed. In five cases the recipient belonged to group $A$, type $M$, and received group $A$, type $N$, cells stored with RP.3300, and group $O$, type $M$, cells stored without RP.3300. In post-transfusion samples the AN cells were counted after differential agglutination with anti-M, and the $O M$ cells after differential agglutination with anti-A. The sixth recipient was group $A, R h$ positive, and received group $A, R h$ negative cells (stored with RP.3300) and group O, Rh positive cells (controls) : in this case an anti-Rh serum was used instead of anti-M in counting the surviving A cells.

On the day of transfusion four bottles of blood of identical age were selected, two having been stored with RP.3300 and two without. The supernatant plasma was withdrawn from each bottle and the red cells were then pooled, in pairs, to provide approximately $500 \mathrm{ml}$. of " test" red cell suspension (stored with RP.3300) and a similar quantity of control red cell suspension (stored without RP.3300). Now $10 \mathrm{ml}$. of a solution of A and B substances (Sharp and Dohme) were added to the concentrated suspension of group $\mathbf{O}$ cells. The two bottles of red cell suspension were transfused in succession in the course of one to two hours. 
Before transfusion each bottle was well mixed and a sample was then withdrawn for red cell counting. The number of red cells counted (for each bottle) was between 2,000 and 3,000 in four cases, and between 4,000 and 6,000 in the remaining two cases. The volume of suspension in each bottle was measured; any residue in the bottle or apparatus at the end of transfusion was also measured and subtracted from the initial total. It was thus possible to estimate, within the limits of the error of the method, the expected ratio of the two types of red cell in the recipient's blood stream, assuming that the two types of red cell survived equally well. Any striking beneficial or harmful effect of RP. 3300 could be detected by a deviation of the ratio found in the recipient's circulation at intervals after transfusion, from the ratio expected.

The technique of differential agglutination was that described by Dacie and Mollison (1943). However, for anti-M counts powdered dry globulin was added directly to a 1 in 100 red cell suspension (Ebert and Emerson, 1946). When anti-A and anti-M counts were performed on the same blood sample, the 1 in 100 suspension for the anti-M counts was prepared from the 1 in 50 suspension used for the anti-A counts, to minimize dilution errors.

The number of cells counted was never less than 2,000, and two-thirds of the estimates were based on counts of more than 4,000 cells.

\section{Experiments in vitro}

Acid-citrate-dextrose, $1 \mathrm{ml}$., or of disodium citrate solution, containing the required concentration of RP.3300, was placed in a clean, glass, capped bottle and autoclaved for 20 minutes at $20 \mathrm{lb}$. $/ \mathrm{sq}$. in. pressure at $121^{\circ} \mathrm{C}$. Similar bottles containing the anticoagulant solution alone were prepared for control samples. Then $4 \mathrm{ml}$. of whole heparinized blood were added to each bottle, with sterile precautions. Blood samples were stored either at $4^{\circ} \mathrm{C}$. or at $37^{\circ} \mathrm{C}$.

Haemoglobin Concentrations. - These were determined as oxyhaemoglobin using a photoelectric colorimeter.

Haematocrits.-Haematocrits were determined in Wintrobe tubes centrifuged at a radius of $15 \mathrm{~cm}$. for 30 minutes at 3,000 r.p.m.

Osmotic Fragility. - This was determined by the method of Parpart, Lorenz, Parpart, Gregg, and Chase (1947), but omitting the addition of complementary solutions. Fortyfive minutes after adding the red cells to the test solution the tubes were centrifuged at 3,000 r.p.m. for five minutes, and the supernatants withdrawn for colorimetric estimation.

Free Haemoglobin in the Plasma.-This was determined by a modification of the benzidine method of Bing and Baker (1931).

Plasma Potassium.-Determinations were made with a flame photometer (Domingo and Klyne, 1949).

RP.3300.-Determination in plasma was performed by an ether-extraction sulphuric acid oxidation method (Halpern, 1951).

\section{Results}

Clinical Observations.-No changes in blood pressure, respiration, or pulse rate were observed after transfusion and no unusual symptoms were noted. One of the nine recipients developed a febrile reaction, but this did not differ in any way from the ordinary type of febrile reaction due to pyrogens.

Survival of Transfused Red Cells in "Single Population" Experiments.The three recipients in this series received red cells stored with RP.3300 for 23, 27, and 28 days respectively. Estimates made at 24 hours showed that survival did 
not differ significantly from that of red cells stored in acid-citrate-dextrose alone (Table I). Estimates made at $\mathbf{4 8}$ hours confirmed these observations. These cases were not followed further.

TABLE I

The Survival of Red Cells Stored with RP.3300 ("Single Population" EXPERIMENTS)

\begin{tabular}{|c|c|c|c|c|c|}
\hline & & $\begin{array}{l}\text { No. of } \\
\text { Cases }\end{array}$ & \multirow{2}{*}{$\begin{array}{c}\text { Preservative } \\
\text { Solution } \\
\text { A.C.D. }{ }^{2}\end{array}$} & $\begin{array}{l}\text { Time of } \\
\text { Storage } \\
\text { (Days) }\end{array}$ & $\begin{array}{c}\text { Percentage }{ }^{1} \\
\text { Survival } \\
\text { at } 24 \mathrm{Hrs} \text {. }\end{array}$ \\
\hline \multirow{2}{*}{\multicolumn{2}{|c|}{ Loutit and Mollison (1943) }} & 2 & & 20 & 92 \\
\hline & & 7 & A.C.D. & 28 & 81 \\
\hline \multirow{3}{*}{ Present Investigators } & 1. & 1 & A.C.D. + RP. $3300^{3}$ & 23 & 89 \\
\hline & 2. & 1 & A.C.D. + RP. 3300 & 27 & 91 \\
\hline & 3. & 1 & A.C.D. + RP.3300 & 28 & 67 \\
\hline
\end{tabular}

1 The co.leentration of surviving red cells in the sample obtained immediately after transfusion was taken as " $100 \%$ survival."

2 Acid-citrate-dextrose.
3 RP.3300 added to give a final concentration in the blood-anticoagulant mixture of $1 / 10,000$.

In "Double Population" Experiments.-For the sake of simplicity the expected ratio, based on the numbers of the two types of red cell transfused, has in each of the six cases been converted to unity, and the ratios found in the recipient's circulation have been multiplied by the same factors.

For example, Mrs. T. was one of the two patients who received blood stored for 27 days (see Fig. 1). A concentrated suspension of red cells, $477 \mathrm{ml}$., count $7.19 \times 10^{6} /$ c.mm., stored with RP.3300, was first transfused, followed by $534 \mathrm{ml}$. of a suspension of red cells, count $6.98 \times 10^{6} / \mathrm{c} . \mathrm{mm}$., stored in acid-citrate-dextrose alone. (The red cell estimates were based on counts of 4,000 cells.) Thus the expected ratio of the two types of red cell in the patient's circulation after transfusion was:

$$
\frac{477 \times 7.19}{534 \times 6.98}=0.92
$$

Estimates made on the following morning gave the following results: A cells (" test" population) $0.611 \times 10^{6} / \mathrm{c}$.mm.; O cells (" control" population) $0.747 \times$ $10^{6} / \mathrm{c} . \mathrm{mm}$. (The estimates were based on counts of approximately 6,000 cells ; in each case a pre-transfusion blank of 10,000 unagglutinated cells per c.mm. was subtracted from the observed count.) The ratio was thus

$$
\frac{611}{747}=0.818
$$

Converting the ratio expected to 1.0 , the ratio found was

$$
0.818 \times \frac{1.0}{0.92}=0.89 \text {, }
$$


and this is the ratio entered on Fig. 1. Thus a ratio of

$$
\frac{\text { survival of test cells }}{\text { survival of control cells }}
$$

which is less than 1 indicates an adverse effect of RP.3300, and a ratio greater than 1 a favourable effect. The results in the six cases are displayed graphically in Fig. 1. Twenty-four hours after transfusion survival is better than expected in two cases, but worse than expected in four cases. In five cases examined between 40 and 60 days after transfusion survival is as good as that of the control in one case, but is worse than that of the control in the remaining four cases.

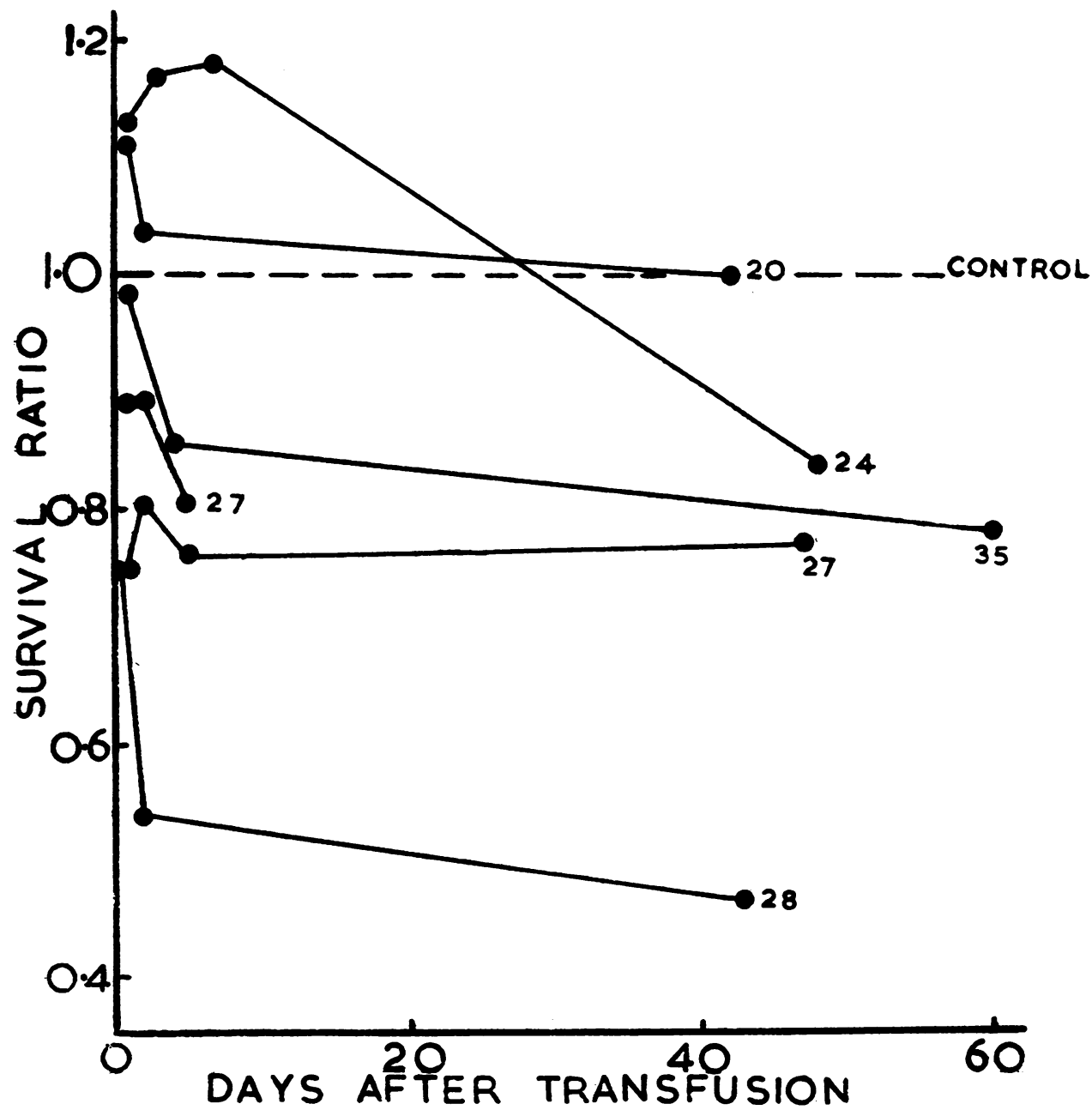

FIG. 1.-The post-transfusion survival of red calls stored in acid-citrate-dextrose with RP. 3300 compared with that of red cells stored in acid-citrate-dextrose alone (control). The figures at the end of each curve indicate the previous length of storage in days. 
Amount of RP.3300 in the Blood after Storage.- In view of a personal communication from Halpern that RP.3300 oxidizes on storage, it was considered desirable to demonstrate that blood which had been stored with RP.3300 for several weeks still contained an adequate amount of the compound.

Accordingly the supernatant plasma-diluent from a bottle of blood stored for 35 days was examined ; the concentration of RP.3300 was found to be approximately 1 in 12,000. (The original concentration in the mixture of blood and diluent was 1 in 10,000 ; assuming that no RP. 3300 entered the red cells, the concentration in the plasma-diluent may originally have been as high as 1 in 7,000.) The observed concentration is within the range which had previously been considered optimal for storage and certainly within the range known to produce "beneficial" effects in vitro.

Spontaneous Haemolysis on Storage.-Blood to which RP.3300 had been added to give a final concentration of 1 in 10,000 haemolysed less rapidly than did control samples, whether stored at $37^{\circ} \mathrm{C}$. or $4^{\circ} \mathrm{C}$. RP.3300 in a final concentration of 1 in 20,000 produced slightly less effect; a final concentration of 1 in 5,000 produced immediate haemolysis of varying degrees. Some typical results are set out in Tables II and III.

The diminution in the rate of spontaneous haemolysis produced by RP.3300 was very obvious in the whole bottles of blood used for transfusion. Whereas the super-

TABLE II

Plasma Haemoglobin Before and After Storage at $4^{\circ}$ C. in A.C.D. With and WITHOUT RP.3300

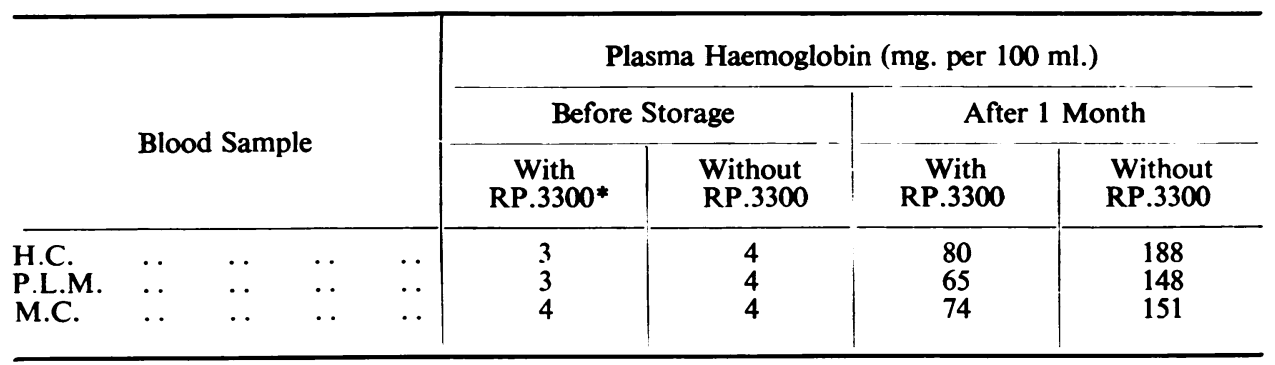

* RP. 3300 was used in a final dilution of 1 in 10,000 . Value given $=$ mean of two or more samples.

TABLE III

Plasma Haemoglobin Before and After Storage at $4^{\circ} \mathrm{C}$. in Disodium Citrate With AND WITHOUT RP.3300

\begin{tabular}{|c|c|c|c|c|c|c|c|}
\hline \multirow{3}{*}{\multicolumn{2}{|c|}{$\begin{array}{l}\text { Blood } \\
\text { Sample }\end{array}$}} & \multicolumn{5}{|c|}{ Plasma Haemoglobin (mg. per $100 \mathrm{ml}$.) } & \\
\hline & & \multicolumn{3}{|c|}{ Before Storage 1} & \multicolumn{3}{|c|}{ After 14 Days $^{2}$} \\
\hline & & $\begin{array}{c}\text { RP.3300 } \\
(1 / 10,000)\end{array}$ & $\begin{array}{l}\text { RP.3300 } \\
(1 / 20,000)\end{array}$ & $\begin{array}{l}\text { Without } \\
\text { RP.3300 }\end{array}$ & $\begin{array}{l}\text { RP.3300 } \\
(1 / 10,000)\end{array}$ & $\begin{array}{l}\text { RP.3300 } \\
(1 / 20,000)\end{array}$ & $\begin{array}{l}\text { Without } \\
\text { RP.3300 }\end{array}$ \\
\hline $\begin{array}{l}\text { H.C.J. } \\
\text { P.L.M. } \\
\text { H.C. }\end{array}$ & \begin{tabular}{l|l}
$\cdots$ \\
$\cdots$ \\
$\cdots$
\end{tabular} & $\begin{array}{r}9 \\
7 \\
11\end{array}$ & $\begin{array}{l}6 \\
7 \\
9\end{array}$ & $\begin{array}{l}4 \\
5 \\
6\end{array}$ & $\begin{array}{l}43 \\
17 \\
23\end{array}$ & $\begin{array}{l}64 \\
27 \\
30\end{array}$ & $\begin{array}{l}75 \\
64 \\
83\end{array}$ \\
\hline
\end{tabular}

${ }^{1}$ Single samples. ${ }^{2}$ Mean of two samples. 
natant plasma of the control bottles, stored without RP.3300 for 20 to 35 days, was usually tinged with free haemoglobin, that of the bottles stored with RP.3300 for the same period was always a light yellow, free from any trace of pink.

Osmotic Fragility.-Blood samples containing RP.3300, stored at $4^{\circ}$ C. or at $37^{\circ} \mathrm{C}$., showed an increased resistance to hypotonic saline; an example is given in Table IV. Again, RP.3300 in a final concentration of 1 in 20,000 had less effect than a final concentration of 1 in 10,000 .

TABLE IV

Percentage Haemolysis in $0.55 \%$ Buffered Saline After One Month's Storage at $4^{\circ}$ C. IN A.C.D. With AND Without RP.3300 in a Final Dilution of 1 in 10,000

\begin{tabular}{|c|c|c|c|c|c|c|}
\hline & \multirow{2}{*}{\multicolumn{4}{|c|}{ Blood Sample }} & \multicolumn{2}{|c|}{ Percentage Haemolysis } \\
\hline & & & & & With RP.3300 & Without RP.3300 \\
\hline $\begin{array}{l}\text { H.C. } \\
\text { M.C. } \\
\text { P.L.M. }\end{array}$ & $\begin{array}{l}\cdots \\
\cdots \\
\cdots\end{array}$ & $\begin{array}{l}\cdots \\
\cdots \\
\cdots\end{array}$ & $\begin{array}{l}\ldots \\
\ldots \\
\ldots\end{array}$ & $\begin{array}{l}\ldots \\
\cdots \\
\cdots\end{array}$ & $\begin{array}{r}15 \\
4 \\
6\end{array}$ & $\begin{array}{l}43 \\
37 \\
28\end{array}$ \\
\hline
\end{tabular}

It was observed that fresh red cells added to hypotonic saline solutions to which RP.3300 had been added to a final concentration of 1 in 40,000 showed less haemolysis than in a control solution containing hypotonic saline alone. In order to balance the effect on tonicity and $p \mathrm{H}$ produced by the small amount of RP.3300 solution added, an equal volume of an equimolar solution of ammonium chloride was added to the control.

As shown in Table $\mathrm{V}$ red cells added to the test solution showed strikingly less haemolysis than in the controls. RP.3300 appeared to exert this effect even in a final concentration of 1 in 160,000 .

TABLE V

Percentage Haemolysis in 0.45\% Buffered Saline with RP.3300 Added in VARIOUS CONCENTRATIONS

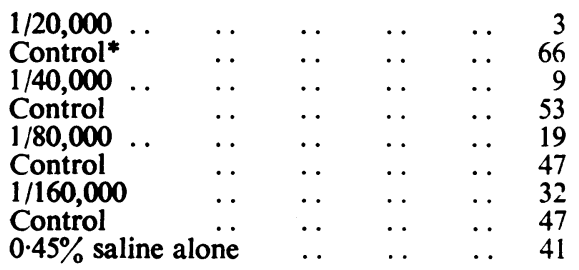

\footnotetext{
* In each case the same volume of an equimolar solution of ammonium chloride was added to a tube of saline to serve as a control.
}

Plasma Potassium Level.-In blood samples stored with acid-citrate-dextrose the addition of RP.3300 resulted in a slightly increased loss of potassium from the cells into the plasma in most cases (Table VI). However, in samples stored with disodium citrate (without dextrose) the addition of RP.3300 in a final concentration of 1 in 10,000 and 1 in 20,000 produced no significant effects (Table VII).

Cell Swelling.- In blood stored with acid-citrate-dextrose + RP.3300 (final concentration 1 in 10,000) for one month the mean corpuscular haemoglobin concentration was consistently higher than in blood stored with acid-citrate-dextrose alone 
TABLE VI

Plasma Potassium Before and After Storage in A.C.D. at $4^{\circ}$ C. For 31 Days With AND Without RP.3300 in a Final Dilution of 1 in 10,000

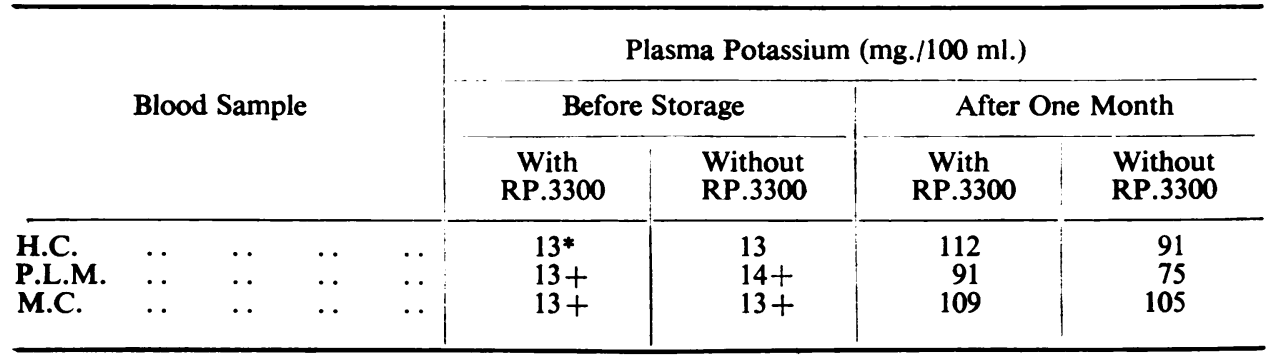

- Values are the mean of estimates on two samples, except those marked + , which are based on single estimates.

TABLE VII

Plasma Potassium in mg. Per 100 ml. after 14 Days' Storage in Disodium Citrate AT $4^{\circ}$ C. WITH AND WITHOUT RP.3300

\begin{tabular}{lcc|c|c|c|c}
\hline \multicolumn{3}{c|}{ Blood Sample } & & $\begin{array}{r}\text { RP.3300 } \\
(1 / 10,000)\end{array}$ & $\begin{array}{c}\text { RP.3300 } \\
(1 / 20,000)\end{array}$ & $\begin{array}{c}\text { Without } \\
\text { RP.3300 }\end{array}$ \\
\hline H.C.J. & $\cdots$ & $\cdots$ & $\cdots$ & 101 & 102 & 97 \\
P.L.M. & $\cdots$ & $\cdots$ & $\cdots$ & 74 & 72 & 72 \\
H.C. & $\cdots$ & $\cdots$ & $\cdots$ & 82 & 68 & 71 \\
\hline
\end{tabular}

(Table VIII). The slightly greater haemolysis of samples stored without RP.3300 was not taken into account in calculating mean corpuscular haemoglobin concentration and would in any case slightly increase the difference. It is concluded that red cells are slightly less swollen after storage with RP. 3300 .

Anti-sphering Effect on Red Cells.- Red cells sphered by repeated washing in normal saline buffered to $p \mathrm{H} 7.4$ were instantaneously reconverted to biconcave discs when added as a weak suspension to buffered saline containing RP.3300 in concentrations of 1 in 10,000 to 1 in 80,000 . This effect could then be reversed by

TABLE VIII

Mean Corpuscular Haemoglobin CONCEntration After Storage for 31 Days in A.C.D. at $4^{\circ}$ C. With and Without RP.3300 in a Final Dilution of 1 in 10,000

\begin{tabular}{|c|c|c|c|c|c|c|}
\hline \multirow{2}{*}{\multicolumn{5}{|c|}{ Blood Sample }} & \multicolumn{2}{|c|}{$\begin{array}{c}\text { Mean Corpuscular Haemoglobin } \\
\text { Concentration }(\%)\end{array}$} \\
\hline & & & & & With RP.3300 & Without RP.3300 \\
\hline \multirow{3}{*}{ H.C. } & \multirow{3}{*}{\multicolumn{2}{|c|}{. $\quad \cdots$}} & 1. & & $27 \cdot 8$ & $25 \cdot 4$ \\
\hline & & & 2. & & $27 \cdot 2$ & $25 \cdot 6$ \\
\hline & & & 3. & & $28 \cdot 2$ & $26 \cdot 2$ \\
\hline M.C. & . & & .. & . & $28 \cdot 0$ & $24 \cdot 6$ \\
\hline P.L.M. & . & & . & . & $26 \cdot 9$ & $24 \cdot 4$ \\
\hline
\end{tabular}


washing the cells once and resuspending them in buffered saline. Since RP.3300 lowers the $p \mathrm{H}$ of unbuffered solutions, it was at first thought that the antisphering might merely be due to acidification as observed using dilute hydrochloric acid, or other soluble hydrochlorides, for example, adrenaline hydrochloride. However, in solutions buffered in the $p \mathrm{H}$ range 6.4-7.4, dilute $\mathrm{HCl}$ and adrenaline hydrochloride have no antisphering activity, whereas the activity of RP.3300 is apparently unchanged.

Effect on Red Cell Antigens.-Since RP.3300 seemed to exert its effects primarily on the surface of the red cell, it was decided to test its effect on agglutinability. Suspensions, 1 in 50 , of red cells of group $A$, type $\mathrm{M}, \mathrm{Rh}$ positive, were mixed with anti-M, anti-Rh, and anti-A sera, and the number of free cells was counted, after following the normal technique of differential agglutination. Red cells from the same donor, suspended in saline containing a final concentration of 1 in 40,000 RP.3300 and treated similarly, gave equally low counts. It was concluded that RP.3300 did not significantly affect the agglutination of human red cells.

Haemolytic Effects of RP.3300.-RP.3300 is haemolytic in concentrations exceeding 1 in 10,000 , and the effect is increased by separating the red cells from their own plasma or by repeatedly washing them with normal saline. In this respect it resembles many other known lytic agents (saponin, bile salts, lecithin, etc.), and a time dilution curve (Ponder, 1948) plotted for 50\% haemolysis was found to be essentially similar to those obtained for many other haemolysins. Similarly, the effects of temperature upon the haemolytic effects of RP.3300 were measured, and were essentially comparable to the temperature-haemolysis relationships of a number of other lytic agents.

Effect on Saponin Haemolysis. - It is well known that certain substances inhibit the haemolysis by saponin of washed red cells, while other substances act as accelerators of saponin haemolysis. Many of the "saponin accelerators" are themselves lytic, and, like RP.3300, many of them are surface-tension-reducing agents. RP.3300 in a dilution of 1 in 2,000 was found to be only slightly less lytic than saponin in a 1 in 100 dilution (50\% haemolysis occurring in approximately 15 minutes in saline buffered to $p \mathrm{H} 7.4$ and kept at $20^{\circ} \mathrm{C}$.). However, when washed red cells were exposed to a solution containing both RP.3300 and saponin, at final concentrations of 1 in 2,000 and 1 in 100 respectively, total haemolysis occurred in less than 60 seconds. Lessening degrees of the accelerating effect of RP.3300 on saponin haemolysis could be demonstrated in dilutions up to 1 in 500,000 .

\section{Discussion}

The results of the transfusion experiments show clearly that RP.3300 is not a red cell preservative in the sense of prolonging viability during storage. Indeed, the results suggest that the compound reduces viability.

It is necessary to reconcile this finding with the apparently beneficial effects of RP.3300 in vitro. The most striking of these effects is the retardation of spontaneous haemolysis. This can hardly be due to the diminished swelling of red cells stored in the presence of RP.3300, for this effect is a very slight one and, in any case, it has been shown previously that the spontaneous haemolysis of red cells during storage begins before the red cells have reached their critical volume (Mollison and 
Young, 1942). It is possible that the spontaneous haemolysis of red cells during storage depends upon some enzyme activity with which RP.3300 interferes.

The present findings did not demonstrate any effect of RP.3300 on the rate of potassium loss from red cells stored in an acid-citrate solution. Although this result appears to contradict the findings of Halpern, Dreyfus, and Bourdon (1950), it should be noted that these workers used a different acid-citrate solution.

In a preservative solution containing dextrose it appears that RP.3300 increases the rate of loss of potassium from the red cells and this effect may be related to the diminished swelling of red cells stored in the presence of dextrose and RP.3300.

The immediate effects produced by suitable dilutions of RP.3300, i.e. antisphering and an increase in the resistance of red cells to hypotonic haemolysis, are presumably related to the "surface-activity" of the compound. Ponder (1948) notes that a number of haemolytic compounds, when used in sublytic doses, increase resistance to hypotonic haemolysis. Furthermore he points out that there are a number of substances which act as antisphering agents but that only plasma and plasma components can effect these changes without going on to produce haemolysis. It seems reasonable therefore to conclude that RP.3300 is a haemolytic substance which in sub-haemolytic concentrations produces a number of superficially favourable effects on stored blood but which exerts no fundamentally beneficial effects upon red cell preservation.

\section{Summary}

The addition of the phenothiazine derivative RP.3300 to blood does not increase its storage life, as judged by tests in vivo. Indeed, its effects appear to be mildly deleterious.

The apparently favourable effects produced by this compound in vitro resemble those of certain haemolytic substances, used in sublytic doses.

We should like to thank Boots Pure Drug Co. Ltd. for drawing our attention to the work of Dr. B. N. Halpern on RP.3300, and to Dr. Halpern himself for a generous supply of the compound and for letting us have details of an unpublished method for its estimation. We are greatly indebted to the director and staff of the North London Blood Supply Depot for allowing us to select suitable donors and for the collection of the blood. Miss A. Rogers, of the Department of Biochemistry in the Postgraduate Medical School of London, kindly performed the potassium estimations.

\section{REFERENCES}

Bing, F. C., and Baker, R. W. (1931). J. biol. Chem., 92, 589.

Dacie, J. V., and Mollison, P. L. (1943). Lancet, 1, 550.

Domingo, W. R., and Klyne, W. (1949). Biochem. J., 45, 400.

Ebert, R. V., and Emerson, C. P. (1946). J. clin. Invest., 25, 627.

Halpern, B. N. (1947). J. Allergy, 18, 263.

(1950). Acta allerg. Kbh., 3, suppl. 1, p. 164.

(1951). Personal communication.

- and Bessis, M. (1950). C.R. Soc. Biol., Paris, 144, 759.

- Dreyfus, B., and Bourdon, G. (1950). Pr. méd., 58, 1151.

- and Hamburger, J. (1948). Canad. med. Ass. J., 59, 322.

- and Reuse, J. (1949). C.R. Acad. Sci.. Paris, 228, 514.

Loutit, J. F., and Mollison, P. L. (1943). Brit. med. J., 2, 744.

Mollison, P. L., and Young, I. M. (1942). Quart. J. exp. Physiol., 31, 359.

Parpart, A. K., Lorenz, P. B., Parpart, E. R., Gregg, J. R., and Chase, A. M. (1947). J. clin. Invest., 26, 636.

Ponder, E. H. (1948). Hemolysis and Related Phenomena. London.

Wurmser, R. (1946). Rev. Hémat., 1, 112. 